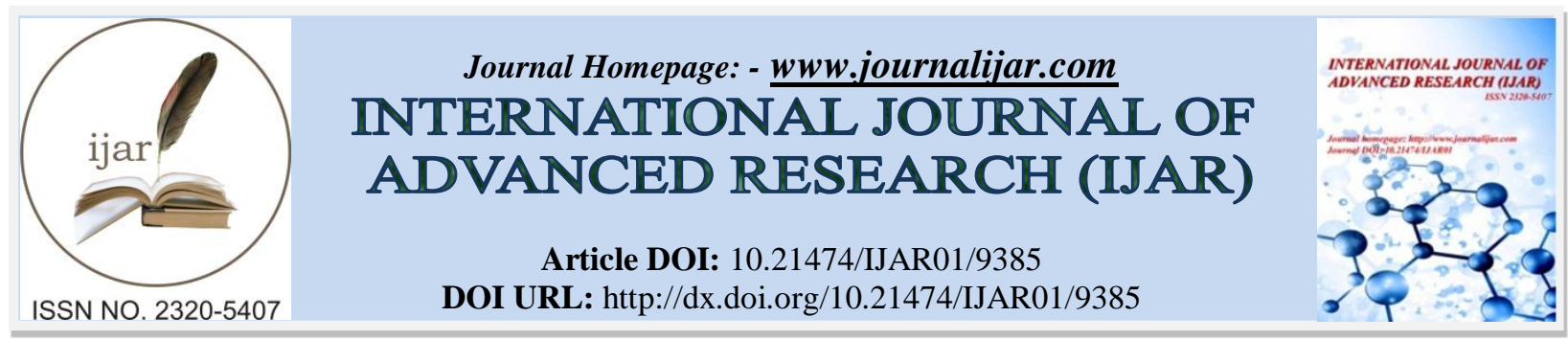

RESEARCH ARTICLE

\title{
SEASONAL BODY MASS CHANGES IN PIED FLYCATCHER (FICEDULA HYPOLEUCA) AT TWO STOPOVER SITES IN MOROCCO.
}

Souad Zerdouk, Houda Hadi, Abdelaziz Benhoussa and *Hamid Rguibi Idrissi.

Laboratory "Biodiversity, Ecology and Genome", Center of Research "Plant Biotechnology, Microbial, Biodiversity and Environment" University Mohammed V, Faculty of Sciences, Rabat, Morocco.

\section{Manuscript Info}

Manuscript History

Received: 15 May 2019

Final Accepted: 17 June 2019

Published: July 2019

Key words:-

Ficedula hypoleuca, migration strategy, body mass, stopover ecology, Morocco.

\begin{abstract}
Seasonal body mass changes during stopover were investigated for the pied flycatchers Ficedula hypoleuca stopping over at two sites in Morocco, reed bed in Larache on the Atlantic coast, and Ramsar Smir on the Mediterranean coast. Estimation of stopover duration was done using the recent method by Schaub et al. (2001). We investigated effects of age and site on body mass parameters and to describe the diet in terms of prey composition to further interpret these data in relation to migration strategy during the stopover in Morocco.

Body mass and fat reserves all increased markedly during the day since first capture. These changes in body mass were strongly associated with the observed changes in fat reserves. The prey size distribution differed significantly between the two site with birds at reed bed in Larache fed larger prey than at Ramsar Smir.
\end{abstract}

Copy Right, IJAR, 2019,. All rights reserved.

\section{Introduction:-}

Body condition is an important parameter determinant of an individual birds fitness, and its implications are of great interest to ecologists. Between migratory flights, birds must replenish energy stores in order to successfully complete their journey (Berthold et al., 1991; Bairlein, 1996; Bairlein and Gwinner, 1994). The rate at which birds change mass during stopover should be an index of site quality (Alerstem and Hendenström 1998, Weber et al. 1994). However, many authors have study the relationship between body mass condition and ecological parameters. The body mass of birds changes during the day of migration (Haftorn, 1989), being lowest at dawn and highest at, or just before, dusk (Kontogiannis, 1967). The low mass is attributable to the overnight emptying of the gut, depletion of fat reserves and water loss (Heibert, 1991). The energetic condition is an important parameter of the strategy of birds.

Many species of passerines pass through Morocco on their way from their breeding grounds in Europe to their wintering area in tropical Africa. A large proportion of these migrants stop in Morocco. Morocco is a "keystone" and plays a major role in the migration and wintering of several Palaearctic-African passerines, following the great diversity of wetlands (Rguibi Idriss,i 2002) used as stopover sites by trans-Saharan migrants. During spring migration, the birds arrive in Morocco, after crossing the Sahara, with depleted fat reserves (Rguibi Idrissi, 2002; Rguibi Idrissi et al., 2003). Hence, we can assume that body mass of migrants in Morocco will be heavier in autumn than during spring, and that capture rates in spring will be higher than in autumn because more birds land in order to replenish their reserves. On the other hand, there are factors which may cause fewer migratory birds to appear in Morocco during spring, such as loop migration (Rguibi Idrissi et al., 2007) and mortality during migration. Some

Corresponding Author:- Souad Zerdouk.

Address:- Laboratory "Biodiversity, Ecology and Genome", Center of Research "Plant Biotechnology,

Microbial, Biodiversity and Environment" University Mohammed V, Faculty of Sciences, Rabat,

Morocco. 
species winter in Morocco, and it is predicted that their body mass will be lighter in autumn, after arrival, than in spring, before setting off for their breeding grounds.

Study of mass change at many stopover sites may help to study the difference migration strategies between species. Some data suggest that migration strategies my be considerably different even in closely related species of passerines migrants (Bibby and Green, 1981; Ellegren, 1990, 1991; Schaub and Jenni, 2000, Casimir et al., 2003; Rguibi et al., 2003) with variation in the time period and location at which maximum fuel loads accumulated (Gargallo and al;, 2011).

In this paper, we analyze body mass and feeding ecology in a long-distance migrant, the Pied Flycatcher Ficedula hypoleuca, during autumn and spring migration. The data were collected by captures in nets at two stopover sites in Morocco : reed bed in Larache (Atlantic coast) and Kebacha (Mediterranean coast) (fig. 1), in several years (nine season-year-site combinations). The main aim was to compare the body mass variation between seasons, sites and age-classes and to describe the diet in terms of prey composition to further interpret these data in relation to migration strategy during the stopover in Morocco.

\section{Materials and Methods:-}

\section{Species}

The Pied Flycatcher is a trans-Saharan migrant (Bernis, 1961) with a breeding range extending from Fennoscandia down to southeast Europe and northwest Africa (Glutz Von Blotzheim and Baeur ,1991). Its wintering grounds are mostly confined to the western part of tropical Africa (Moreau, 1972) including countries such as Guinea, Gambia, South Mali and Ghana (Urban et al., 1997; Gargallo and al;, 2011).

However, the European Pied flycatchers were separate in three species Ficedula albicollis, Ficedula semitorquata and Ficedula hypoleuca with two ss. species iberia in Spain and speculigera in North Africa (Saetre et al. , 2001).

In Morocco, the Atlas Pied flycatcher (F.hypoleuca speculigera) is observed during both spring and autumn migrations (Rguibi Idrissi, 2002, Rguibi Idrissi et al., 2007). However, in winter season some individuals for this specie were tendency to concentrate at relatively few areas in Morocco (Rguibi Idrissi et al., 2007).

\section{Data set}

In both localities, the nets were concentrated in a limited area where capture effort was thus maximized. Birds were identified to the species level, banded with a numbered aluminium ring (Helgoland rings, Wilhelmshaven, Germany), weighed to the nearest $0.1 \mathrm{~g}$ with a Salter spring balance $(60 \mathrm{~g})$, and their wing chord measured to the nearest $1 \mathrm{~mm}$ (Bairlein, 1995). The amount of subcutaneous body fat was estimated on a scale of 0 (no visible fat on the abdomen or in the furculum) to 8 ( fat bulging both on the abdomen and the furculum) (Kaiser 1993). Most individuals were aged, separating birds in their first years (Svensson, 1992, Jenni and Winkler, 1994).

Some individuals were administered a $1 \%$ solution of antimony potassium tartrate, according to the method of Poulin and Lefebvre (1995). The solution was made one month before sampling to reduce the toxicity of the chemical. On the other hand, only the birds captured over two hours after sunrise were forced to regurgitate. Treated birds were given $0.08 \mathrm{ml}$ of solution per $10 \mathrm{~g}$ body mass through a $1.5 \mathrm{~m}$ diameter flexible plastic tube attached to a $1 \mathrm{ml}$ syringe. The chemical was then slowly administered, and the bird placed in a small dark box lined with absorbent paper. Birds were released 20-30 minutes later, and regurgitated items were preserved in 70\% ethanol.

For the analysis of body mass and fat reserves, we tested for differences in these variables between seasons (spring and autumn), sites and age groups, using the General Linear Model (GLM). Diets characteristics were compared between sites by means of classical statistical tests (Likelihood ratio G-tests, ANOVAs).

A total of 461 individuals pied flycatchers were trapped, and the totals for each site and age groups are show in Table 1. 


\section{Results:-}

I. ANALYSIS OF POPULATION WEIGHT

The mean body weight of the whole sample was $13.66 \mathrm{~g} \pm 1.39(\mathrm{n}=338)$ and ranged between $10.0 \mathrm{~g}$ and $17.3 \mathrm{~g}$ during autumn migration, and $12.21 \mathrm{~g} \pm 1.25(\mathrm{n}=123)$ and ranged between $9.90 \mathrm{~g}$ and $18.30 \mathrm{~g}$ during spring migration. The results of the analysis of variance of the weight in two stopover sites appear in Table 2.

An analysis of variance (Table 2) demonstrates that age, although a significant factor, juvenile birds appear little heavy than the adults. Moreover, results from analysis of variance revealed that only body mass and age and site were significantly related to the date of passage (Table 1). There was a considerable season effect on body mass, with individuals weighing on average $1.07 \mathrm{~g}$ more in autumn than in spring (Table 2). Adults tended to be heavier than juveniles (main effect of age: $+0.1 \mathrm{~g}$ for adults vs. first year) across sites and seasons, but a significant season $\mathrm{x}$ site interaction indicated that birds of all ages were able to gain weight at an unaffected rate and that arriving or departing birds had different weight during migration (Fig. 2).

Body mass and fat reserves all increased markedly during the day since first capture (Table 2). These changes in body mass were strongly associated with the observed changes in fat reserves (Fig. 3).

\section{Potential PREY ABUNDANCE}

In total 129 and 250 food items were identified in the 26 and 15 emetic samples selected at reed bed in Larache and Ramsar Smir, respectively from across the season. A comparison of the relative proportion of the major invertebrates-groups identified differed significantly between the two sites ( $\mathrm{t}$-test for unequal variances: $\mathrm{t}=3.83$, $\mathrm{df}=$ $17, \mathrm{p}=0.001$ ) suggesting differences in food intake between sites. The prey size (ranged between 2.5 and $7.5 \mathrm{~mm}$ ) distribution differed significantly between the two site $(\mathrm{G}=2.512$, $\mathrm{df}=4, \mathrm{p}=0.05)$ with birds at reed bed in Larache fed larger prey than at Ramsar Smir.

\section{Discussions:-}

The body mass of the individuals birds can vary widely during migration (Blem, 1990). Many theoretical analyses suggest that this variation reflects the differences between the costs and benefits of fat storage (McNamara and Houston, 1990; Houston and McNamara, 1993).

Our data demonstrated that autumn birds of Pied flycatchers captured at two stopover sites were able to accumulate body mass (fat stores) faster during the day than spring birds. Several hypotheses may explain why spring migrants gained mass at a somewhat slower rate than autumn birds. First, the duration of the stopover in autumn migration leading to reduced selective pressure for short stopovers and rapidly body mass gain (Burger 1988; Wunderle 1991; Rguibi Idrissi et al,. 2003), or, the competition potential among individuals juveniles and adults during stopover at two sites, forcing some birds to use less favourable habitats at each site resulting in lowered rates of mass gain. In the other hand, we have found in our research on the Reed warblers (Rguibi Idrissi et al., 200; 2004; 2007) that variation of stopover and foraging patterns was age-related. Stopover duration was longer for juveniles than for adults and longer in autumn than in spring. Adults tended to be heavier than juveniles across sites and seasons.

The rate of body mass varied among site, seasons and age-groups. The rate of mass estimated based on the slopes of the regressions between body mass and capture time (Fig. 2) may estimate the mass change because many migrants were probably rehydrating after nocturnal flight and therefore appeared to be gaining mass more rapidly than they actually were. Body mass differences between adults and juveniles birds were usually small but apparently sufficient enough for birds to base stopover decisions on. Similar age-specific differences in body mass occurred in Pied flycatchers in Spain (Veiga, 1986), Sedge warblers in Northern Italy (Spina and Bezzi ,1990), Bluethroats in Sweeden (Ellegren, 1991) and Reed warblers in Morocco (Rguibi Idrissi et al., 2003). Is likely that these differences reflect different migration strategies in autumn and spring, together with geographical influences, fattening strategy (Rogers, 1987) and predictability of their food resource. Indeed, during migration, birds respond to decreased food availability by increasing body mass and energy reserves (Biebach, 1990; Bairlein, 1991; Rogers, 1995; Witter et al., 1995; Witter and Swaddle, 1997; Chernetsov and Titov, 2000), moreover, birds can reduce body mass and energy reserves under increased risk of predation (Witter et al., 1994). Generally, migration strategy assumes that there is a negative relation between stopover, variation of body mass and fatting rate (Bairlein, 1990, 1998; Alerstam and Lindeström, 1990). The differences in body mass of pied flycatchers between sites could be attributed to a declining availability of food between sites and between age-groups the mass loss could be due to low post-fledging foraging 
efficiency. The foraging strategy of pied flycatchers during autumn migration shows that birds in Atlantic site exploit a greater diversity of prey of large size than in Mediterranean site which birds fed on small prey. However, the manipulations of food availability influenced either absolute levels of body mass or the pattern of change mass during the day of capture. This explains the variation rate of body mass between season and age-groups at both sites, although less pronounced at the Atlantic site.

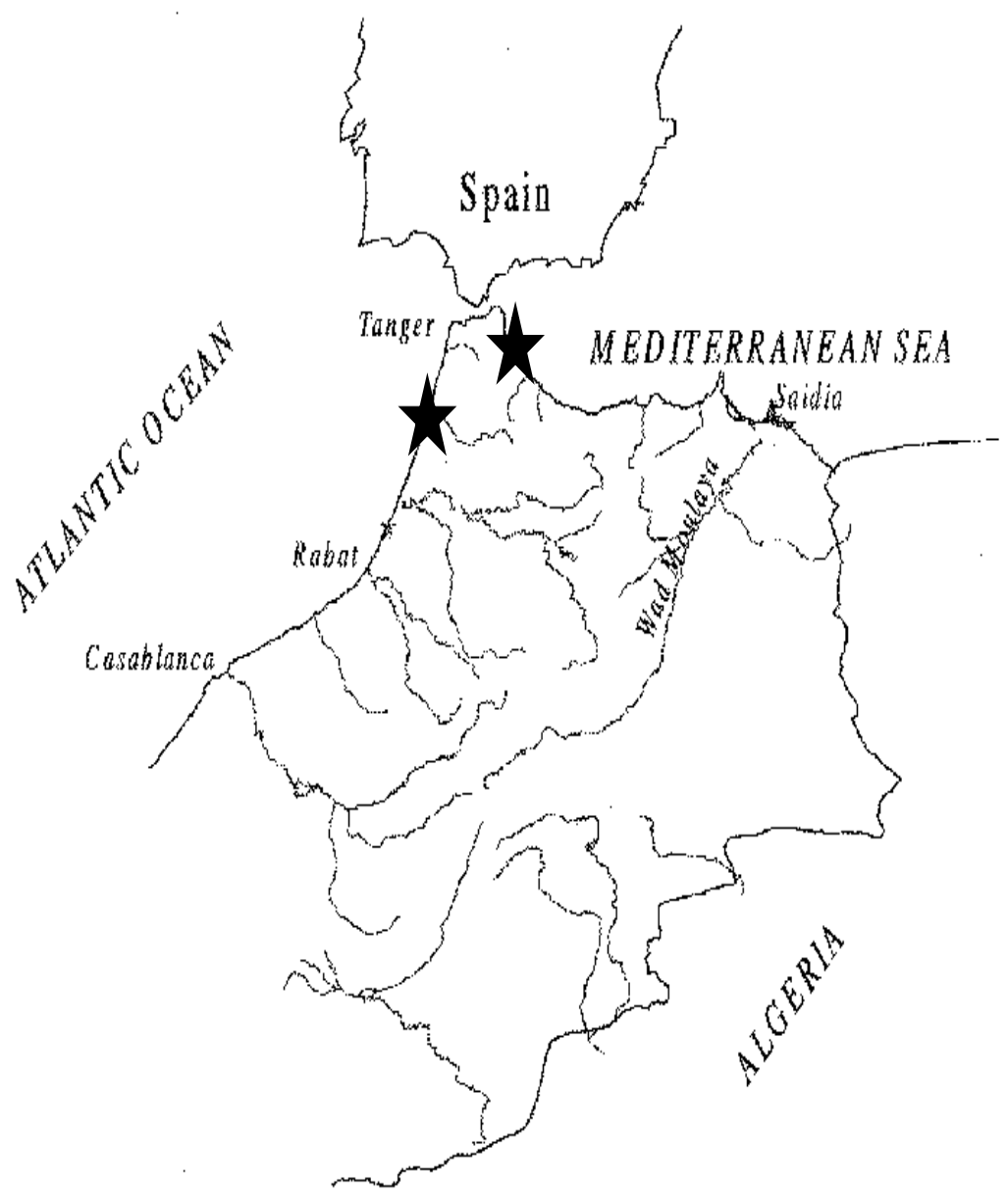

Figure 1. Location of the two study site in Morocco 
Adjusted body mass

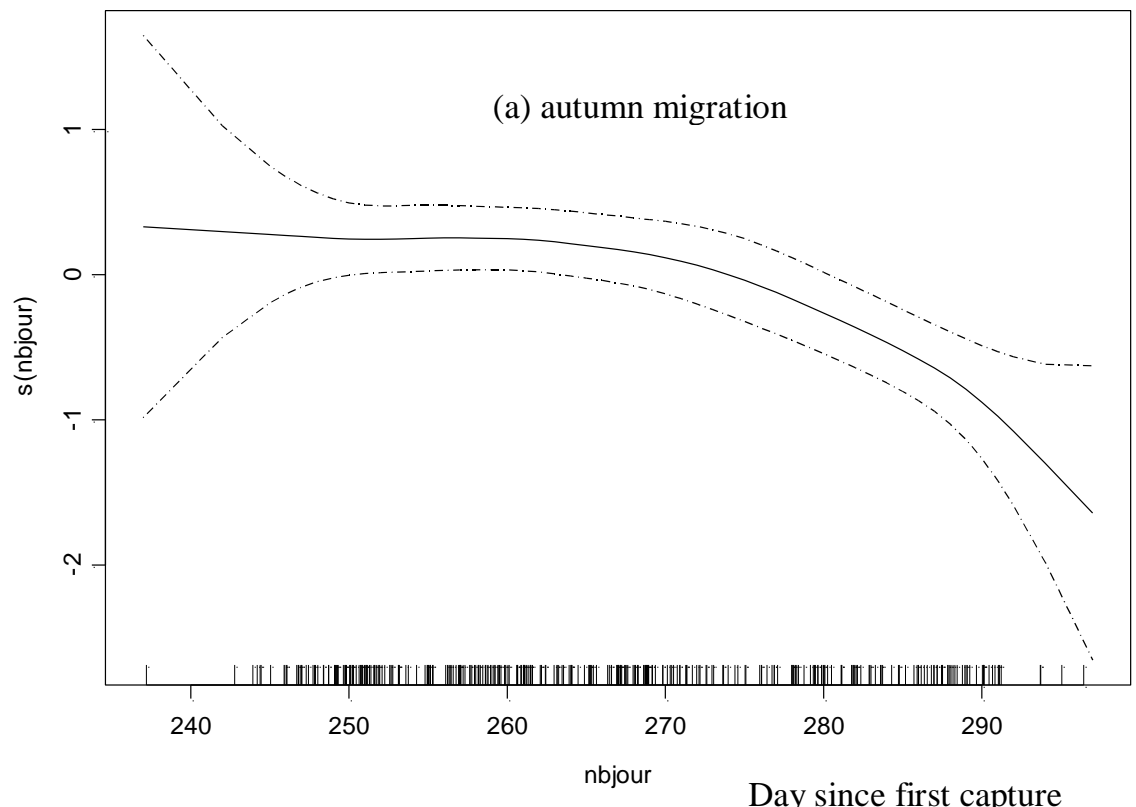

Figure 2. The relationship between body mass (g) and number of days after first capture of Pied flycatchers recaptured at two stopover sites in Morocco during migration: (a) autumn migration and (b) spring migration. Data were analysed with GAM modelling, adjusting weight among individuals. Small vertical bars on the $x$-axis show the distribution of data. Broken lines are $95 \%$ confidence limits.

Adjusted body mass

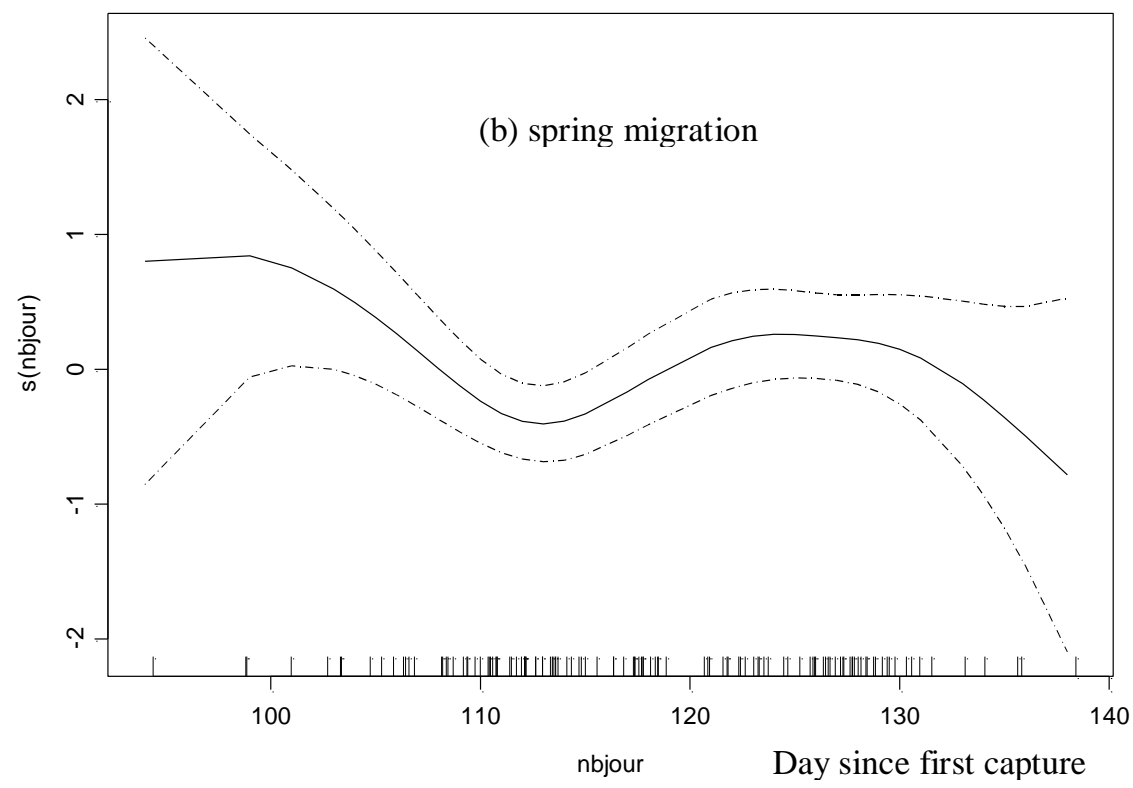

Figure 3. The relationships between the body mass and fat score. The relationship is show as the raw data from a representative individual. For fat score analysing the relationship across all birds with a mixed-model ANCOVA, there is a highly positive association between fat score and body mass $(\mathrm{F} 1,451=78.11, \mathrm{p}<0.0001)$. The regression equation with the mean \pm se of the individual regression coefficients from each bird is: body mass $=10.97$ $( \pm 0.1)+0.7( \pm 0.03)$ fat score. 


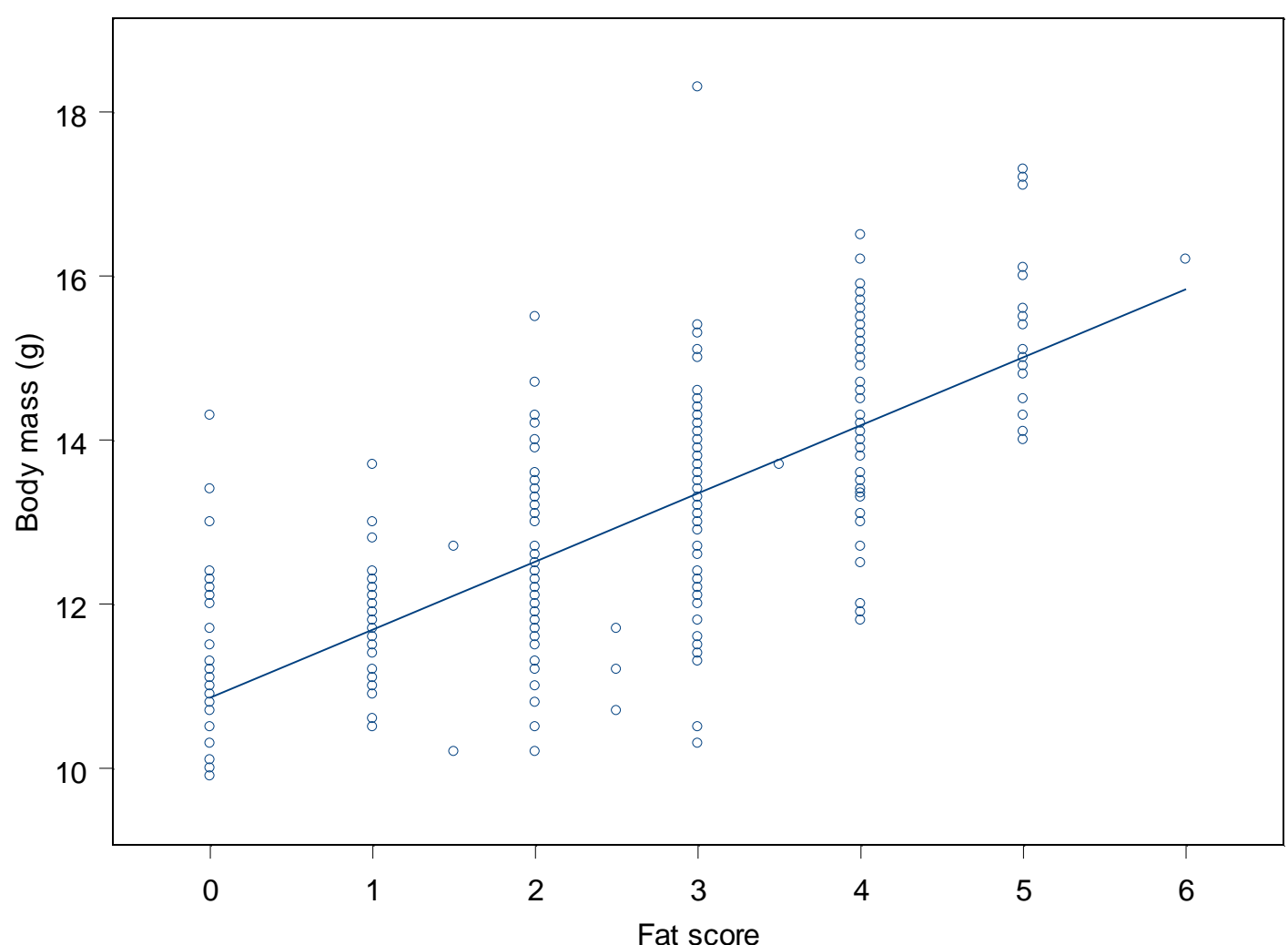

\begin{tabular}{|c|c|c|c|c|c|c|}
\hline & Ramsar $S n$ & & & Red bed Larac & & \\
\hline & Number of & apture (mean wi & $g( \pm S D))$ & Number of cap & ure (mean wing & $\pm S D)$ ) \\
\hline Season & $\begin{array}{l}\text { Date } \\
\text { capture }\end{array}$ & Juvenilles & Adults & $\begin{array}{l}\text { Date of } \\
\text { capture }\end{array}$ & Juvenilles & Adults \\
\hline $\begin{array}{l}\text { Automn } \\
2012\end{array}$ & $\begin{array}{l}10 / 9- \\
29 / 10\end{array}$ & $49(13.4 \pm 1.52)$ & $\begin{array}{l}13 \\
(13.9 \pm 0.94)\end{array}$ & $10 / 9-29 / 10$ & $\begin{array}{l}20 \\
(12.7 \pm 1.38)\end{array}$ & $10(13.5 \pm 0.78)$ \\
\hline $\begin{array}{l}\text { Automn } \\
2013\end{array}$ & $\begin{array}{l}16 / 8- \\
26 / 10\end{array}$ & $42(14.2 \pm 0.9)$ & $\begin{array}{l}16 \\
(14.3 \pm 0.91)\end{array}$ & & & \\
\hline $\begin{array}{l}\text { Automn } \\
2014\end{array}$ & & & & $19 / 8-20 / 10$ & $\begin{array}{l}56 \\
(14.1 \pm 0.52)\end{array}$ & $25(14.3 \pm 0.76)$ \\
\hline $\begin{array}{l}\text { Automn } \\
2015\end{array}$ & & & & $1 / 9-26 / 10$ & $\begin{array}{l}59 \\
(13.35 \pm 0.99) \\
\end{array}$ & $46(13.2 \pm 1.33)$ \\
\hline $\begin{array}{l}\text { Spring } \\
2012\end{array}$ & $15 / 4-15 / 5$ & $9(12.6 \pm 0.81)$ & $\begin{array}{l}24 \\
(12.0 \pm 0.72)\end{array}$ & & & \\
\hline $\begin{array}{l}\text { Spring } \\
2013\end{array}$ & $3 / 4-29 / 5$ & $47(12.3 \pm 1.05)$ & $\begin{array}{l}28 \\
11.8 \pm 0.81)\end{array}$ & & & \\
\hline $\begin{array}{l}\text { Spring } \\
2014\end{array}$ & & & & $27 / 3-7 / 6$ & $3(13.2 \pm 0.89)$ & $5(13.3 \pm 0.64)$ \\
\hline $\begin{array}{l}\text { Spring } \\
2015\end{array}$ & & & & $30 / 3-21 / 5$ & $2(13 \pm 1)$ & $5(12.8 \pm 0.84)$ \\
\hline
\end{tabular}

Table 1. Total number of juvenile and adult Pied flycatcher trapped during stopover at two sites in Morocco. 
Table 2 . Modelling body mass and fat score variation at first capture for all individuals captured. Interactions: A : Age, Si : Site, Se : Season, D : Day

\begin{tabular}{|l|l|l|l|l|l|l|}
\hline & \multicolumn{4}{l}{$(\mathrm{a})$ Variation of Body mass } & \multicolumn{1}{l|}{ III. $(B)$ VARIATION OF FAT } \\
\hline Effect & Df & F & P & Df & F & P \\
\hline Age & 1 & 4.67 & 0.03 & 1 & 0.01 & 0.8 \\
\hline Season & 1 & 92.23 & $<0.0001$ & 1 & 56.08 & $<0.0001$ \\
\hline Site & 1 & 18.20 & $<0.0001$ & 1 & 42.41 & $<0.0001$ \\
\hline Day & 1 & 21.54 & $<0.0001$ & 1 & 7.43 & 0.006 \\
\hline AxSe & 1 & 0.60 & 0.4 & 1 & 0.0 & 0.9 \\
\hline AxSi & 1 & 1.47 & 0.2 & 1 & 0.44 & 0.5 \\
\hline AxD & 1 & 10.38 & 0.001 & 1 & 8.68 & 0.003 \\
\hline SexSi & 1 & 14.35 & $<0.0001$ & 1 & 5.56 & 0.01 \\
\hline SexD & 1 & 0.79 & 0.3 & 1 & 2.22 & 0.1 \\
\hline SixD & 1 & 17.15 & $<0.0001$ & 1 & 30.89 & $<0.0001$ \\
\hline AxSexSxD & 1 & 0.62 & 0.4 & 1 & 0.12 & 0.7 \\
\hline
\end{tabular}

\section{Bibliography:-}

1. Alerstam, T. and Hedenström, A. (1998): The development of bird migration theory. J. Avian Biol. 29: $343-369$.

2. Atbib, M. (1979) : Etude phyto-écologique de la réserve biologique de Mehdia (littoral atlantique du Maroc). 1: la végétation hygrophile de la Merja reed bed in Larache. Bull. Inst. Sci. Rabat 4: 99-188.

3. Bairlein, F. (1991à: Body mass of Garden warblers Sylvia borin on migration : a review of field data. Vogelwarte 36: 48-61.

4. Bairlein, F. (1996): Long-term ecological studies on birds. Verh. Dtsch. Zool. Ges. 89.2: 165-179.

5. Bairlein, F. and. Gwinner, E. (1994): Nutritional mechanisms and temporal control of migratory energy accumulation in birds. Annu. Rev. Nutr. 14: 187-215.

6. Berthold, P. and Terrill, S.B. (1991): Recent advances in studies of bird migration. Annu. Rev. Ecol. Syst. 22: 357-378.

7. Bibby, C.J. and Green, R.E. (1981): Autumn migration strategies of Reed and sedge warblers. Ornis Scand. 12: $1-13$.

8. Blem, C.R. 1990. Avian energy storage. Curr. Ornithol., 7: 59-113.

9. Bolshakov, C.V.; Bulyuk, V.N.; Mukhin, A. and Chernetsov, N. (2003): Body mass and fat reserves of Sedges warblers during vernal nocturnal migration: departure versus arrival. J. Field Ornithol. 74 (1): 81-89.

10. Ellegren, H. (1990): Autumn migration speed in Scandinavian Bluethroat Luscinia s. svecica. Ring. Migr. 11: 121-131.

11. Ellegren, H. (1991): Stopover ecology of autumn migrating Bluethroats Luscinia s. svecica in relation to age and sex. Ornis Scand. 22: 340-348.

12. Glutz Von Blotzheim, U. and Baeur, K.M (1991): Handbuch der Vögel Mitteleuropas. Band 12. Aula-Verlag, Wiesbaden.

13. Harrache, M. (1994) : Etude écologique de la végétéation dunaire specialisée de la réserve biologique de mehdia (littoral atlantique, maroc) en vue de l'establissement d'un plan de gestion. Thèse de zème cycle. Aixmarseille III University.

14. Houston, A.I. and Mcnamara, J.M. (1993): A theoretical investigation of the fat reserves and mortality levels of small birds in winter. Ornis Scand. 24: 205-219.

15. Jenni, L. and Winkler, R. (1994): Moult and Ageing of European Passerines. London: Academic Press

16. McNamara, J.M. and Houston, A.I. (1990): The value of fat reserves and the tradeoff between starvation and predation. Acta biotheor. 38: 37-61.

17. Poulin, B. and Lefebvre, G. (1995): Additional information on the use of tartar emetic in determining the diet of tropical birds. Condor 97: 897-902.

18. Rguibi Idrissi, H. ;. Dakki, M and Bairlein, F. (2007): Migration et hivernage de quelques passereaux au Maroc. Mise au point à partir des données de baguage et reprise. Ostrich 78: 343-347

19. Rguibi Idrissi, H.; Lefebvre, G. and Poulin, B. (2004): Diet of Reed warblers Acrocephalus scirpaceus at two sites in Morocco during autumn migration. Rev. Eco. Terre Vie 59: 491-502.

20. Rguibi-Idrissi, H. (2002): Analyse comparative de la migration de quelques passereaux au Maroc à l'aide des données de baguage et d'un suivi dans deux zones humides. Thèse de Doctorat, University Rabat. 
21. Rguibi Idrissi, H., Julliard, R. and Bairlein, F. (2003): Variation in the stopover duration of Reed Warblers Acrocephalus scirpaceus in Morocco: effects of season, age and site. Ibis 145: 203-215.

22. Shaub, M and Jenni, L. (2000): Fuel deposition of three passerine birds species along the migratory route. Oecologia 122: 306-317.

23. Svensson, L. (1992): Identification Guide to European Passerines, 4th edn. Stockholm.

24. Weber, T.P., Houston, A.I. and Ens, J.B. (1994): Optimal departure fat loads and stopover-site use in avian migration: an analytical model. Proceedings of the Royal Society London B 258: 29-34. 